\title{
水秦拡散火资の数值シミュレーション*
}

\author{
高 城 敏 美*1, 多田勝 已*2, 小宮山 正治*1
}

\section{Numerical Simulation of the Hydrogen Diffusion Flame}

\author{
Toshimi TAKAGI, Katsumi TADA, and Masaharu KOMIYAMA
}

\begin{abstract}
Numerical simulation of the laminar hydrogen diffusion flame was conducted based on the conservation equations taking into account the multicomponent diffusion and chemical kinetics employing elementary reactions. Computed results were compared with the experimental ones. The following was concluded : (1) the computations can well predict the measured profiles of species concentration and temperature, (2) concentration overshoot of $\mathrm{OH}, \mathrm{O}$, and $\mathrm{H}$, the maximum reaction rate and heat release rate are larger near the nozzle exit than in the downstream region, ( 3 ) selective diffusion of $\mathrm{H}_{2}$ and $\mathrm{H}$ induces the concentration of $\mathrm{H}_{2}$ near the reaction zone and the outer part of the flame, (4) reactions related to $\mathrm{HO}_{2}$ contribute to the conversion of $\mathrm{H}$ into $\mathrm{H}_{2} \mathrm{O}$ through $\mathrm{HO}_{2}$ near the outer part of the flame.
\end{abstract}

Key Words: Numerical Simulation, Hydrogen, Laminar Diffusion Flame, Elementary Reaction, Multicomponent Diffusion, Chemical Kinetics

\section{1. まえがき}

拡散燃焼は典型的な燃焼形態の一つでありその基礎 過程を調べることは各種類似の火炎構造の理解, 乱流 拡散火炎の微視的火炎構造の考察にも役立つと考えら れる。

本報では水素の同軸流層流拡散火炎を対象として素 反応に基づく反応動力学と多成分拡散を考慮して数值 シミュレーションする，その結果を実験と比較し，数 值シミュレーションにより火炎をどの程度予測できる かを調べる。また，火炎内の非平衡性，選択拡散の影 響，どのような反応過程が火炎内のどの領域で生じる かを調べ, 火炎の微視的な構造を明確にしようとす る.

反応動力学を考慮した層流拡散火炎の数值予測は, $\mathrm{H}_{2}$ 火炎(1) $\mathrm{CH}_{4}$ 火炎 $^{(2)(3)}$ 等において行われているが, 本報では主要ガス濃度, 温度, $\mathrm{OH}$ の相対濃度等の分 布の測定值とも比較しながら，考察を加える。

*年成 2 年 3 月 24 日 関西支部第 65 期定時総会講演会にお

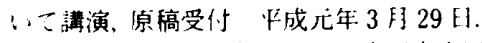

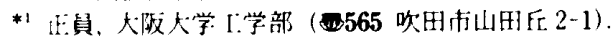

*2 学生員, 大阪大学大学院.

\section{2. 基碟 式}

対象とする流れ場は周囲空気流中に円管から気体燃 料を同方向に噴出する同軸噴流火炎であるので, 境界 層流れと考えられる。

定常で軸対称二次元の境界層近似をした保存方程式 は次のとおりである。これらにより火炎内の流速, 化 学種濃度およびエンタルピーが規定される。

質量保存式：

$$
\frac{\partial}{\partial x}(\rho u)+\frac{1}{r} \frac{\partial}{\partial r}(r \rho v)=0
$$

運動量の保存式：

$$
\begin{aligned}
& \frac{\partial}{\partial x}(\rho u u)+\frac{1}{r} \frac{\partial}{\partial r}(r \rho u v) \\
& \quad=-\frac{\partial P}{\partial x}+\frac{1}{r} \frac{\partial}{\partial r}\left(\mu r \frac{\partial u}{\partial r}\right)+\rho g_{x}
\end{aligned}
$$

化学種 $j$ の保存式 :

$$
\begin{aligned}
& \frac{\partial}{\partial x}\left(\text { oum }_{j}\right)+\frac{1}{r}-\frac{\partial}{\partial r}(\text { rovm }) \\
& \quad=\frac{1}{r} \frac{\partial}{\partial r}\left(r \rho D_{j m} \frac{\partial m_{j}}{\partial r}\right)+R_{j}
\end{aligned}
$$

エネルギーの保存式：

$$
\frac{\partial}{\partial x}(\rho u h)+\frac{1}{r} \frac{\partial}{\partial r}(r \rho v h)
$$


2110

$$
=\frac{1}{r} \frac{\partial}{\partial r}\left\{\left(\lambda \frac{\partial T}{\partial r}+\rho \sum_{j} D_{j m} h_{j} \frac{\partial m_{j}}{\partial r}\right)\right\}
$$

$こ こ て ゙, x, r=$ 軸方向, 半径方向の座標, $u, v=$ 軸 方向, 半径方向の流速, $P=$ 圧力, $T=$ 絶対温度, $m_{j}$ $=$ 化学種 $j$ の質量分率, $h, h_{j}=$ 混合ガス, $j$ 成分の工 ンタルピー, $\rho=$ 密度, $g_{x}=x$ 方向重力加速度, $R_{j}=j$ 成分の単位体㮴当たりの生成速度, $\mu=$ 粘性係数, $\lambda=$ 熱伝導率， $D_{j m}=$ 多成分系における $j$ 成分の有効拡散 係数である。ただし，ふく射や粘性による発熱を無視 している.

密度 $\rho$ は完全ガスの状態式から次式で求める.

$$
\rho=\left(P / R_{0} T\right) / \sum_{j}\left(m_{j} / M_{j}\right)
$$

ここで， $R_{0}=$ 一般ガス定数， $M_{j}=$ 成分 $j$ の分子量で ある. 温度 $T$ はエンタルピー $h$ との間に次の関係が ある。

$$
h=\int_{T_{0}}^{T} \sum_{j} m_{j} C_{p j} d T+\sum_{j} h_{j 0} m_{j}
$$

ただし， $C_{p j}=$ 成分 $j$ の定圧比熱， $h_{j 0}=$ 成分 $j$ の標準 生成エンタルピー， $T_{0}=$ 基準温度である， $h$ と $m_{j}$ を 式(3)，（4)から求め机ば, 式（6）から $T$ が求められ る.

上式中の粘性保数および熱伝導率は，各成分のそれ ぞれの物性值と質量分率から求められる混合ガスに対

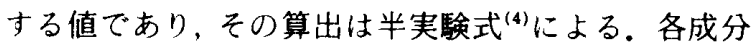
の粘性係数, 熱伝導率および 2 成分系拡散係数の算出 は，文献(4)による。各成分系におけるj成分の有効 拡散係数 $D_{j m}$ は

$$
D_{j m}=\left(1-m_{j}\right) / \sum_{i \neq j}\left(x_{i} / D_{i m}\right)
$$

で求める ${ }^{(4)}$.ここで $x_{i}$ は $i$ 成分のモル分率, $D_{j i}$ は $j$ と $i$ 成分の 2 成分拡散係数である。 $D_{j i}$ は主として文献 (4)に基づく．各成分の比熱 $C_{p_{i}}$ はJANAF 表 ${ }^{(5)} に よ$ る.

\section{3. 慈反応と反応速度定数}

火炎中に存在する成分として, $\mathrm{H}_{2}, \mathrm{O}_{2}, \mathrm{~N}_{2}, \mathrm{H}_{2} \mathrm{O}, \mathrm{O}$, $\mathrm{H}, \mathrm{OH}, \mathrm{HO}_{2}$ の 8 種とし，それらの間の素反応は文献 (1)，（2），(6)〜（8)を参考にし，表1に示したも のを適用する。

各素反応の右向きの反応速度定数 $k_{f}$ は $k_{f}=A T^{n}$ $\exp \left(-E / R_{0} T\right)$ の表示式で与えられるものとし，各素 反応の係数 $A, n$, および活性化エネルギー $E$ は文献 (6)〜（8）を参考にし，表 1 による. 左向きの反応速 度定数は, 右向きの反応速度定数と平衡定数 ${ }^{(5)}$ の比に より求める。

式（３）における $j$ 成分の単位体積, 単位時間当たり の反応量 $R_{j}$ は次式で算出する.

$$
R_{j}=M_{j} \sum_{i=1}^{m}\left(\nu_{j, i}^{\prime \prime}-\nu_{j, i}^{\prime}\right) k_{i} \prod_{l=1}^{s}\left[C_{l}\right]^{\nu, u^{\prime}}
$$

ただし， $\nu_{j, i}^{\prime}, \nu_{j, i}^{\prime \prime}=$ 反応 $i に お け る j$ 成分の反応物，ま たは生成物の量論係数, $k_{i}=$ 反応 $i$ の反応速度定数, $\left[C_{l}\right]=$ 成分lのモル濃度である。また，式（８）におけ る反応 $i$ とは表 1 における各素反応において右向きお よび左向きをそれぞれ別々の反応とみなして考えるも のとする. 表 1 の場合, $m$ はその反応の数の 2 倍で 32 であり, $s$ は化学種の数で 8 である.

\section{4.計算と比较する対象とした実験}

内直径 $4.2 \mathrm{~mm}$ の円管ノズルから, 水素と窒素の体 積混合割合を $30: 70$ としたがス燃料を平均流速 5.2 $\mathrm{m} / \mathrm{s}(R e=1054)$ で噴出させる。噴流周囲に $1.7 \mathrm{~m} / \mathrm{s}$ の 流速で空気を流す。この条件で居流拡散火炎を作る。

火炎内の主要ガス $\left(\mathrm{H}_{2}, \mathrm{O}_{2}, \mathrm{~N}_{2}\right)$ の濃度は内径 0.76 $\mathrm{mm}$ の水冷プローブによってサンプリング後, ガスク ロマトグラフにより分析した。ガス温度はアルゴンイ オンレーザを入射したときのレーリ散乱強度から，ま た $\mathrm{OH}$ の相対濃度分布はエキシマレーザ励起の発光 スペクトル分析から求めたものである ${ }^{(9)}$. 測定は，主 としてノズル先端からの軸方向距離 $L$ が $30 \mathrm{~mm}$ の断 面で行い, $15 \mathrm{~mm}$ の断面についても補足的に行って いる。

\section{5. 計算法と境界条件}

前述の基礎方程式(1)〜（4)および補助式 (5)

\begin{tabular}{|c|c|c|c|c|c|c|}
\hline \multicolumn{3}{|c|}{ 辰充 } & $\wedge$ & $n$ & E & 女酼 \\
\hline (1) & $11+0$ & $=011+0$ & $2.24 E 14$ & 0.0 & 16800 & (6) \\
\hline (2) & 0111 , & $=011+11$ & $1.71 E 13$ & 0.0 & 9450 & (6) \\
\hline (3) & $11,+011$ & $=11+11,0$ & $2.19 E 13$ & 0.0 & 5150 & (6) \\
\hline (4) & $011+O H$ & $=11,11+0$ & $5.75 E 12$ & 0.0 & 780 & (6) \\
\hline (5) a ) & $11+11+11$ & $=11,+11$, & $9.20 E 16$ & -0.6 & 0 & (1) \\
\hline & $\mathrm{H}+\mathrm{H}+\mathrm{N}$, & $=11,+N$, & $1.00 E 18$ & -1.0 & 0 & (7) \\
\hline & $11+11+0$, & $=11.10$, & $1.00 E 18$ & -1.0 & 0 & (7) \\
\hline & $111+11+11=0$ & $=11,111,01$ & $600 E 19$ & -1.25 & 0 & (1) \\
\hline (6) & $11+1+N$ & $=(1)+N$, & $2.62 E 16$ & -0.84 & 0 & (6) \\
\hline (7) & $O H+H+N$. & $=H, O 1, \mathrm{~N}$, & $1.17 E 17$ & 0.0 & 0 & (6) \\
\hline (B) & $\mathrm{H}+0,+\mathrm{M}$, & $=\mathrm{HO}, \mathrm{H} \mathrm{N}_{\mathrm{H}}$ & $2.70 \varepsilon 18$ & -0.86 & 0 & (7) \\
\hline (9) & $11+110=$ & $=011+\|\|$ & $2.50 E 14$ & 0.0 & 1900 & (6) \\
\hline$(10)$ & $11+110$, & $=0 .+11$ & $250 E 13$ & 0.0 & 695 & (6) \\
\hline (11) & $11+110$, & $=11: 0110$ & $5.00 E 13$ & 0.0 & 1000 & (8) \\
\hline (12) & $0+110$, & $=011+0$. & $180 E 13$ & 0.0 & 1000 & (8) \\
\hline (13) & $O H+110$, & $=11,0+0$, & S.00E13 & 0.0 & 1000 & (8) \\
\hline
\end{tabular}
〜 (8) を用いて数值計算により流速, 化学種灌度およ び温度等を算出する。基礎方程式はコントロールボリ ューム法で一次精度風上差分を用いて差分化し，境界

表 1 反応と反応速度定数

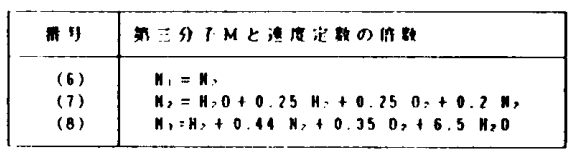


条件を满足させながら，上流から下流へ，逐次積分し ていく。この方法は文献 ${ }^{(10)} に$ 準じる。計算を安定に行 うには, 反応量を求める式 $(8)$ を式 (3)に用いる場合 に，陰的に計算する必要がある。

計算領域は半径方向に中心から $52 \mathrm{~mm}$ までとし， 64 個の不等間隔格子で分割する. 各格子点で物性値 (多成分系の粘性係数, 熱伝萑率, 拡散係数, 密度), 各 素反応の反応量等の計算を行う。

境界条件は前節の実験条件に対応したものとする。 燃料ノスル出口断面において, 従属変数(流速, 各成分 の濃度，エンタルピー）に対して実験に対応した值を 与える。ただし，境界層近似をしているため，ノズルリ ムの火炎の保持のために, ノズルリムに相当する位置 (燃料流と空気流の境界) で燃料ガスと空気が，体積割 合が 1：1で混合したときの断熱平衡の温度および濃 度の条件を与えた。この割合を量論混合比とした場合 でも，後述の計算結果に大きい影響はなかった。対称 軸では半径方向にこう配がないという条件を与え，火 炎から離れた周囲では軸方向の流速, エンタルピーお よび成分濃度の值を与える。

\section{6. 計算結果と検郡}

図 1（a)，(b)は燃料ノズル先端からの距離 $L$ が $15 \mathrm{~mm}$ および $30 \mathrm{~mm}$ の断面での半径方向濃度分布で ある。横軸 $R$ は中心軸からの半径方向距離である. 実 線は計算值, プットは実験值である。濃度はドライ ベース ( $\mathrm{H}_{2} \mathrm{O}$ を除外した濃度)で表示している。いず れの断面も，中心軸近傍では $\mathrm{H}_{2}$ が，周辺部では $\mathrm{O}_{2}$ が 過剩であり, 半径位置 $R=3 \sim 3.5 \mathrm{~mm}$ 近傍で $\mathrm{H}_{2}, \mathrm{O}_{2}$ とも濃度が少なくなり, 量論混合比の䝶度となる，図 1 から, 主要なガス成分濃度について, 計算値は実験 值をかなりよく予測できることがわかる。

図 2 は $L=30 \mathrm{~mm}$ の断面における温度分布の計算 值と測定值の比較を示す。量論混合比近傍では温度は 極大値をとる．計算值は実験值をかなり良く予測して いる.

図 3 は図 1 と同じ断面における活性化学種 $(\mathrm{OH}, \mathrm{O}$, H）の半径方向の㳻度分布の計算値である。 $\mathrm{H}$ は中心 軸に近い $\mathrm{H}_{2}$ 過剩領域で， $\mathrm{O}$ および $\mathrm{OH}$ は量論混合比 に近い領域で亟大值をもつ. H は拡散係数が大きいた め半径方向中心部に広がった分布を持つ。これらの濃 度は平衡湦度よりもかなり大きくなっており，極大值 の近傍では $L=30 \mathrm{~mm}$ の断面で, $\mathrm{H}, \mathrm{OH}, \mathrm{O}$ の濃度 (モル濃度)はその点での平衡濃度に比べて本火炎では それぞ，30，20，200 倍程度となっている． $L=30 \mathrm{~mm}$ の断面に比べて $15 \mathrm{~mm}$ の断面におけるほうが活性化

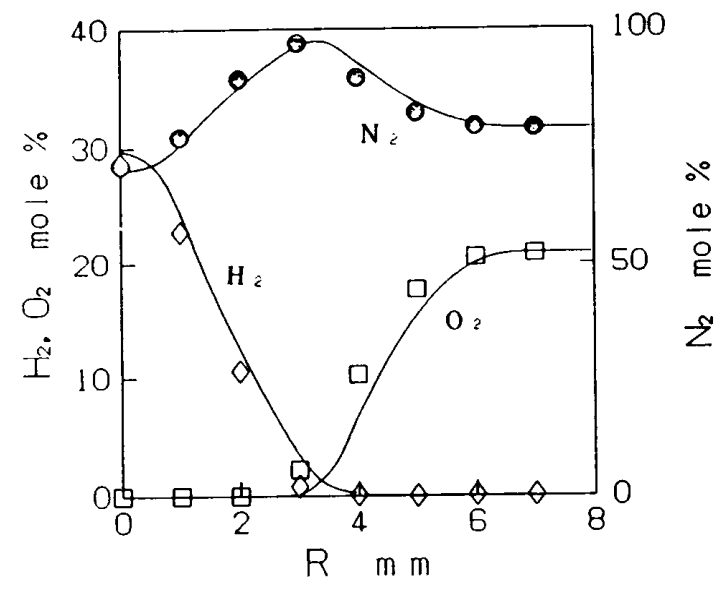

(a) $L=15 \mathrm{~mm}$

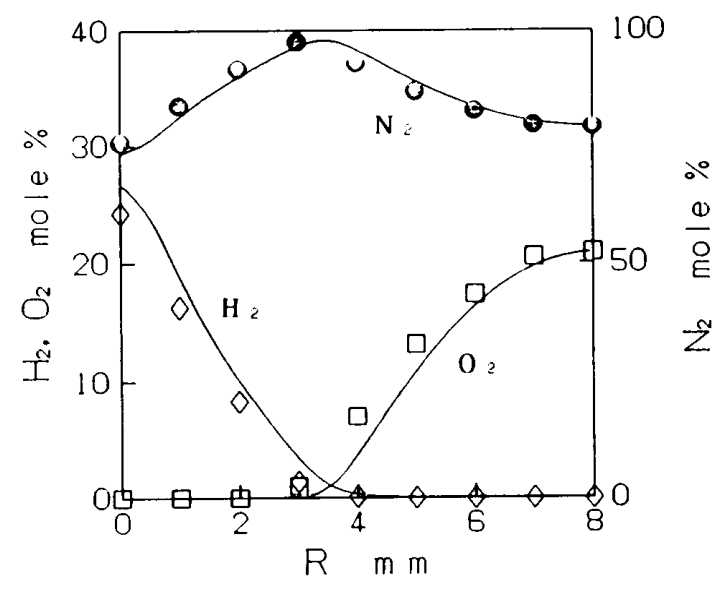

(b) $L=30 \mathrm{~mm}$

図 1 半径方向濃度分布

（実線は計算值，プロットは実験值）

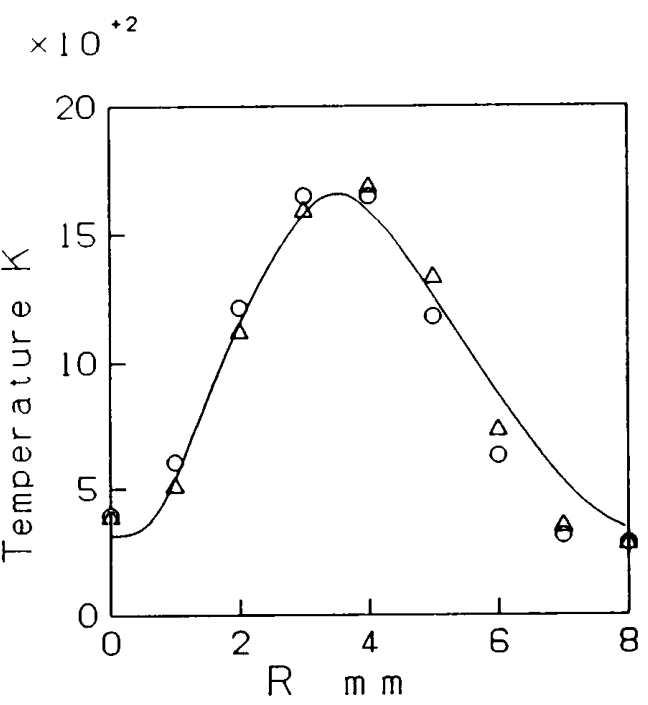

図 2 半径方向温度分布 （実線は計算值，プロットは実験值） 
学種の極大濃度が高くなる傾向がある。これはノズル 先端に近い $L=15 \mathrm{~mm}$ の断面のほうが $\mathrm{H}_{2}$ および $\mathrm{O}_{2}$ の半径方向濃度こう配が急峻であり，火炎帯での拡散 混合速度が大きいことによると考えられる。

図 4 は OH の相対浇度の計算值と実験值の比較で ある。分布の広がりや形状がかなりよく対応している ことがわかる。

以上のように計算值が実験値よりかなりよく予剆で きることから上述の計算は実際の水素拡散火炎をよく 表現できると考えられる。

図 5 は，燃料中の $\mathrm{H}_{2}$ の体積混合割合 $\left(\mathrm{H}_{2}\right.$ Ratio と 称す)の半径方向分布の計算值である。これは, 各点で のすべての反応成分濃度から燃焼前の燃料と空気の混 合割合, ならびに燃料中の $\mathrm{H}_{2}$ の混合割合を逆算して 得られたものである。燃料ノズルから供給される燃料

$$
\times 10^{-2}
$$

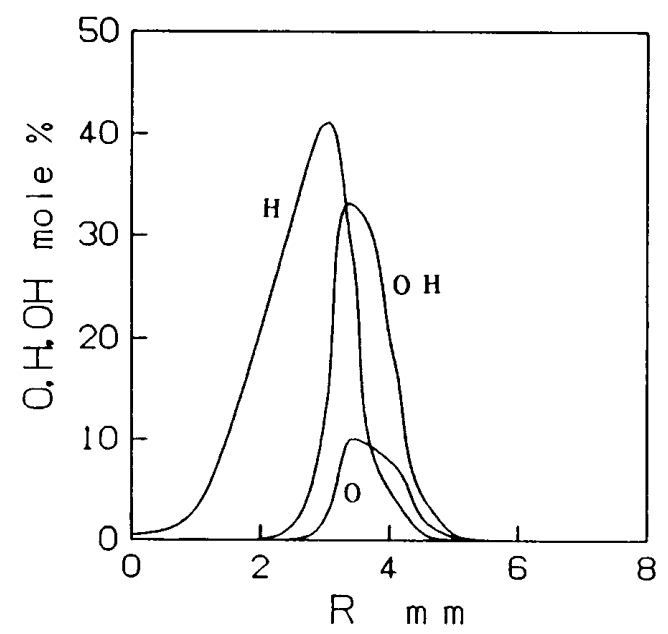

(a) $I .=15 \mathrm{~mm}$

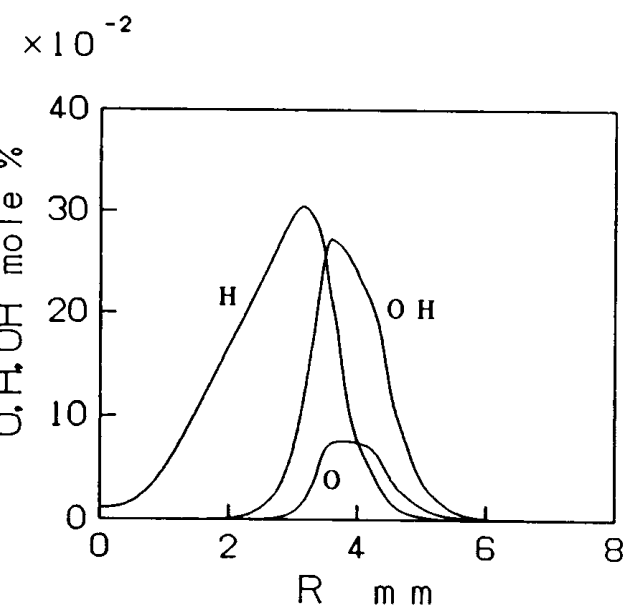

(b) $1 .=30 \mathrm{~mm}$

図 3 活性化学種の半径方向行布
中の $\mathrm{H}_{2}$ の体積割合 $\left(\mathrm{H}_{2}\right.$ Ratio $)$ は 0.3 であるが, $\mathrm{H}_{2}$ お よび $\mathrm{H}$ は $\mathrm{N}_{2}$ に比べて拡散係数が大きいため, $\mathrm{H}_{2}$ の 選択拡散が生じ， $\mathrm{H}_{2}$ Ratio が各場所で変化する. $\mathrm{H}_{2}$ の 多い火炎内部では $\mathrm{H}_{2}$ Ratioは 0.3 より低くなるが, 周辺部では大きくなる.火炎帯と考えられる $R=3$ 〜 3.5 mm では $\mathrm{H}_{2}$ Ratioはノズル出口での值よりも大 きくなる傾向があり，選択扩散の影響は無視できない ことがわかる。

図 6 は各素反応の有効な右向き反応量(=右向き反 応量一左向き反応量)の半径方向分布の計算値である. 各反応番号は表 1 の反応の番号と対応する. 図中の線 上のプロットは計算点のうち数点を選びプロットした もので, プロットの記号の種類により反応番号と対応 させることができるようにしたものである。図 6 (a) は $\mathrm{H}-\mathrm{O}$ 系高速反応および結合反応, 図 6(b) は $\mathrm{H}_{2} \mathrm{O}$ に関連した反応についてのものである。

図 7 は反応による発熱速度の半径方向分布である.

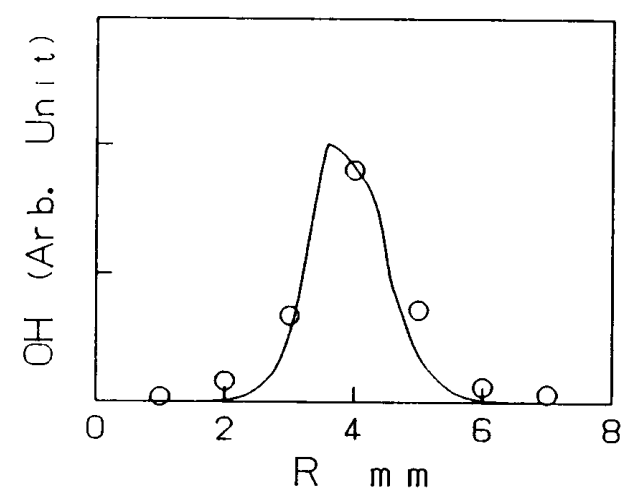

図 4 OH の相対洤度の半径方向分布 （実線は計算值，プロットは実験值） $\times 10^{-2}$

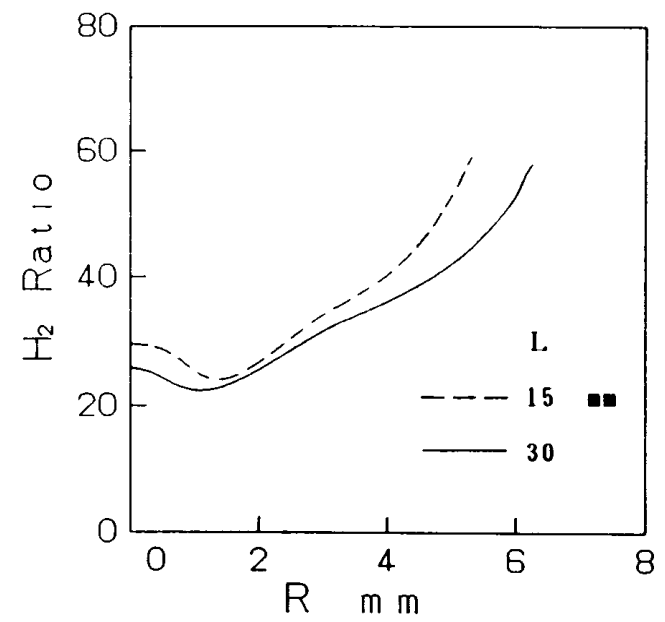

因 5 燃料中の $\mathrm{H}_{2}$ の割合 $\left(\mathrm{H}_{2}\right.$ Ratio $)$ の分布 


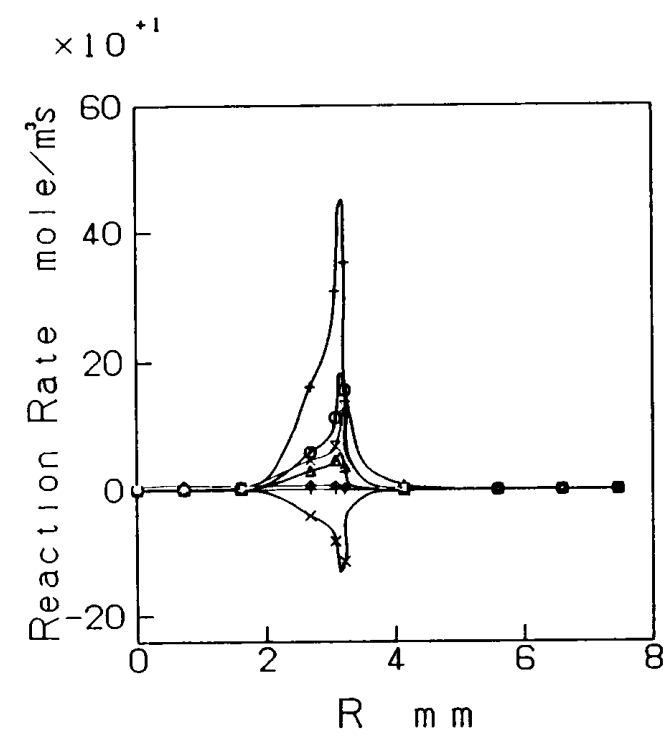

$\begin{array}{llllllll}\text { Reaction number } & 1 & 2 & 3 & 4 & 5 & 6 & 7\end{array}$ symbol $0 \triangle+X \diamond \uparrow 又$

(a) 文伈 (1)-(7)

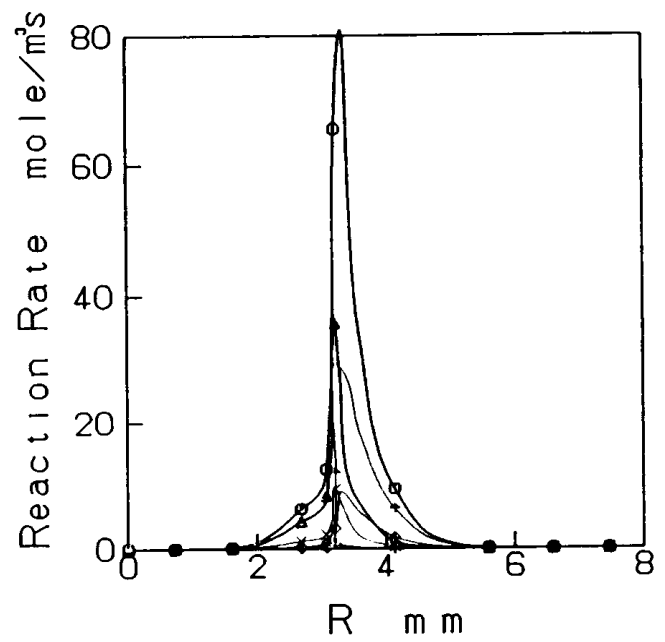

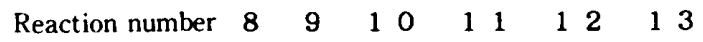
symbol $\bigcirc \triangle+X \diamond 4$

(b) 权迈( (8)-(13)

図 6 各素反応の反応量の半径方向分布

図 6，7および前述の各種分布を対比させると次の ことがいえる。

(a) 反応量の大きい領域（反応領域）は約 $2 \mathrm{~mm}$ 程度以内の幅であり, 温度分布, 活性化学種濃度の広 がりに比べて狭い。また, 反応領域の中間部に狭い反 応量の特に大きい領域がある。

（b）反応量の特に大きい素反応は反応(3)で， $\mathrm{OH}$ 基と $\mathrm{H}_{2}$ が反応して $\mathrm{H}_{2} \mathrm{O}$ と $\mathrm{H}$ が生成する.この反 応の大きい領域が他の反応の反応量の大きい領域とも

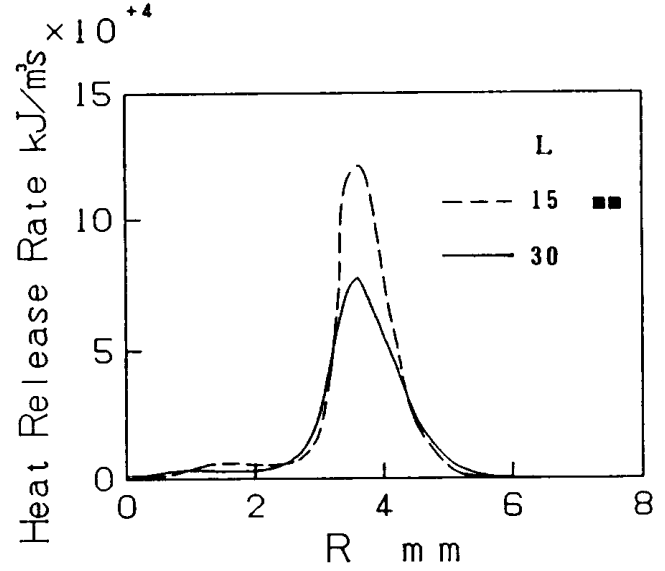

図 7 発熱速度の半径方向分布

対応する.このため, $\mathrm{OH}$ と $\mathrm{H}_{2}$ の濃度がともにある程 度大きい領域が反応領域となっている．各成分漶度の 分布が反応領域よりもかなり広がっているのは拡散に よる.

（c） $\mathrm{H}_{2}$ を分解する反応は（3)が主要で(2)が付 加的に生じる. $\mathrm{O}_{2}$ を分解する反応は (1)である. 反応 ( 1 ) ～( 3 ) が連鎖反応的に生じ, $\mathrm{O}_{2}, \mathrm{H}_{2}$ が $\mathrm{H}_{2} \mathrm{O}, \mathrm{OH}$, $\mathrm{H}, \mathrm{O}$ などに変換されていく，反応 $(4)$ は左向きに生 じ， $\mathrm{H}_{2} \mathrm{O}$ を分解して $\mathrm{OH}$ を生成する. 反応 $(5) \sim(7)$ は結合反応であり，反応 $(7)$ が主要な発熱に寄与す る.

図 7 の発熱速度の分布は図 6 の反応量分布の広がり よりも見かけ上広がっているように見えるのは, 主要 な発熱反応である反応 $(7)$ の反応量の分布に主として 対応するためである，中心軸近傍で発熱があるのは反 伈領域で生成された $\mathrm{H}$ が中心軸近傍へ拡散し，結合 反応 $(5)$ にっって $\mathrm{H}_{2}$ に変換する過程で発熱するため である。

(d) $\mathrm{HO}_{2}$ を含む素反応のうち, 主要なものは反応 ( 8 )である.これによって, $\mathrm{H}$ が $\mathrm{HO}_{2}$ になり，他の反 応で最終的には $\mathrm{H}_{2} \mathrm{O} に$ 変換されていく。このため， $\mathrm{HO}_{2}$ 濃度は大きくないが, $\mathrm{HO}_{2}$ 系の反応を加えるこ とによって $\mathrm{H}$ 原子を消費するので, とくに火炎周辺 部での H 濃度が減少し, 温度が少し上昇する結果と なる。

(e ) $L=15 \mathrm{~mm}$ 断面では $L=30 \mathrm{~mm}$ の断面に比 べて反応による発熱速度の極大值は大きい。また各素 反応の反応量も大きくなる傾向があった．これは図 3 において活性化学種濃度が高いことも対応する. $\mathrm{H}_{2}$ や $\mathrm{O}_{2}$ の半径方向漕度こう配が大きく，㹡散混合速度が 速いためと考えられる。すなわち，反応速度が混合で 律速される傾向があるためと考えられる。 
（f） 発熱速度の分布の広がりは温度分布の広がり よりも狭い，温度分布の広がりには熱伝学が影警する ためである。

\section{7.むす ひ}

（1）素反応に基づく反応動力学と多成分拡散を考 慮すると，水素の層流拉散火炎における主要なガス成 分の婊度, 温度および OH の相対濃度分布の実験値を かなりよく予測できることを示した。

（2）反応領域はガス濃度や分布の広がりに比べて かなり狭い範囲（幅 $2 \mathrm{~mm}$ 以下）に限られる. 反応帯 では活性化学種浱度が平衡浱度よりも著しく超過し， この傾向はノズル出口に近いほど顕著である。また， 反応速度や発熱速度の最大値もノズル出口に近いほど 大きい.

（3） $\mathrm{H}_{2}$ と $\mathrm{H}$ の選択拡散が影響し, 反応帯領域ま たはその周辺部は供給される燃料中の $\mathrm{H}_{2}$ 濃度よりも 高い濃度の燃料が燃焼するように作用する，中心部で は燃料中の $\mathrm{H}_{2}$ 灌度が下がる。

(4) $\mathrm{HO}_{2}$ を含む反応は火炎周辺部に拡散してく る $\mathrm{H}$ 原子を消費し, $\mathrm{HO}_{2}$ を経由し $\mathrm{H}_{2} \mathrm{O}$ に変換する作 用があり，H原子濃度の低下と温度上昇につながる。 このことから， $\mathrm{HO}_{2}$ を含む反応を考虑する必要があ
る.

本研究で用いた実験結果は毛馬大成（大阪大学大学 院), 吉沢豊 (大阪大学工学部), 田中知樹 (大阪大学工 学部) の諸氏の助力によっていることを記し謝意を表 する。

\section{文献}

（1）福谷・神野，第２２问燃焼シンポジウム前刷集。(1984)，67。

（2）体野，然焼ひレーザ計測とモデリング，第 9 章，(1987） 239, 日本機械学会。

（3）森・活加 3 名，機論. 46-410, B (1980)，2052.

(4) Bird. R. B.. Stewart, W. E. and Lightfoot. E. N.. Trans. port Phenomena, (1960), Wiley.

(5) Stuhl, D. R. and Prophet. H., JANAF Thermochemical Tables. 2nd Ed.. (1971-6), U.S. Dept. of Commerce (NSRDS-NBS 37).

(6) Baulch. D. L.. 活か. 3 名. Eialuated Kinetic Data for High Temperatue Reactions, 1 3 (1972-6). Butter Worths.

(7) Dixon.Lewis. G., Combust. Science and Tech. 34 (1983). 1 .

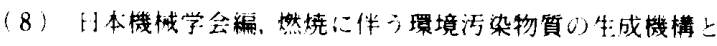
抑制法。(1980).

（9）毛馬・活名４名。関西支部第 64 期定時総会諈演会講演概 要集. No. 894-1 (1989).

(10) Spalding. D. B.. HMT Genmix-A General Computer Program for Turo-Dimension Parabolic Phenomena. (19i7). Pergamon Press. 